\title{
Inhibitory effect of cytotoxic stilbenes related to resveratrol on the expression of the VEGF, hTERT and c-Myc genes
}

Rosa Marti-Centelles, Eva Falomir ${ }^{*}$ Juan Murga, Miguel Carda ${ }^{*}$ and J. Alberto Marco

Graphical Abstract

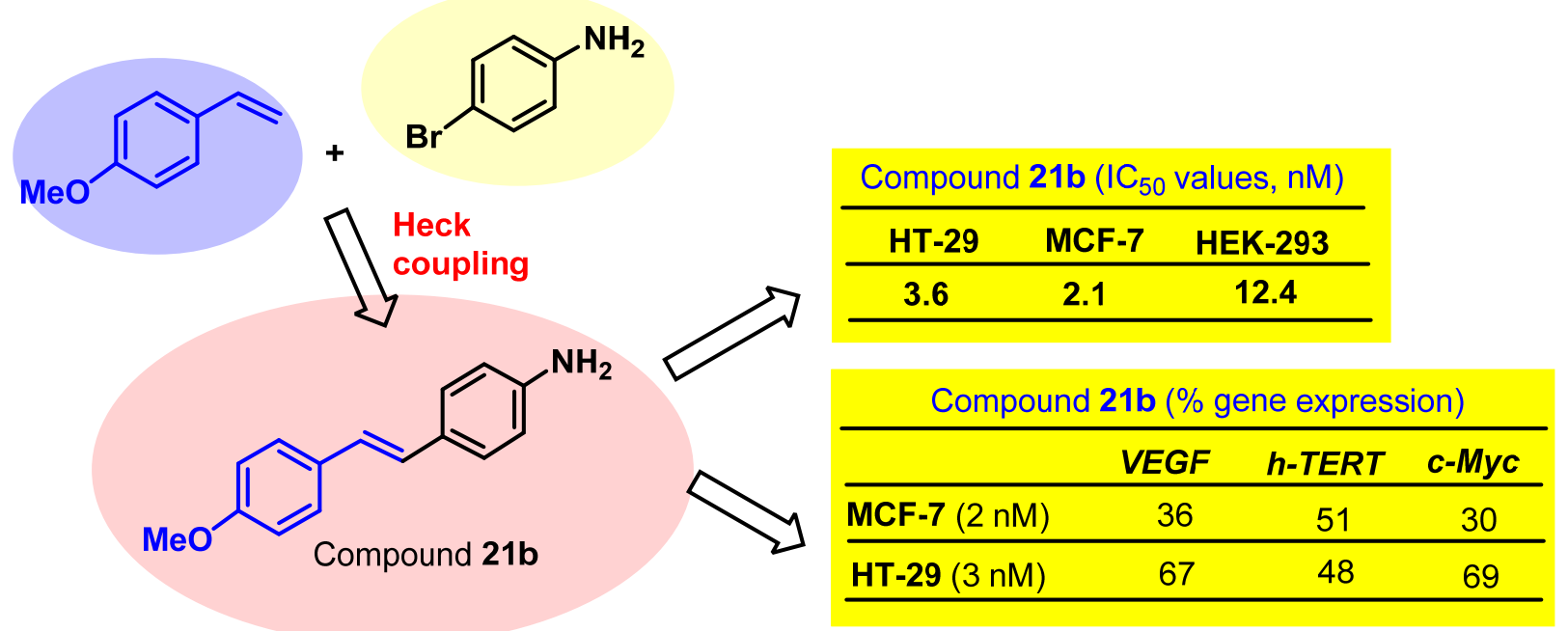

Thirty-nine stilbenes have been prepared. Their cytotoxicities and ability to inhibit the expression of VEGF, h-TERT and c-Myc genes have been measured. One compound is very active in these properties. 


\title{
Inhibitory effect of cytotoxic stilbenes related to resveratrol on the expression of the VEGF, hTERT and c-Myc genes
}

\author{
Rosa Marti-Centelles, ${ }^{a}$ Eva Falomir, ${ }^{a}{ }^{*}$ Juan Murga, ${ }^{a}$ Miguel Carda, $^{a}{ }^{*}$ and J. Alberto Marco ${ }^{b}$
}

åDepart. de Q. Inorgánica y Orgánica, Univ. Jaume I, E-12071 Castellón, Spain

${ }^{\mathrm{b}}$ Depart. de Q. Orgánica, Univ. de Valencia, E-46100 Burjassot, Valencia, Spain

*Authors to whom correspondence should be addressed. E-Mail addresses: efalomir@qio.uji.es, mcarda@qio.uji.es

\begin{abstract}
A group of thirty-nine stilbene derivatives, prepared by means of Heck coupling reactions, has been investigated for their cytotoxicity, as well as for their ability to inhibit the production of the vascular endothelial growth factor (VEGF) and the activation of telomerase. The ability of these compounds to inhibit proliferation of two tumoral cell lines (HT-29 and MCF-7) and one non tumoral cell line (HEK293) was first determined. Subsequently, we determined the capacity of the compounds to inhibit the secretion of VEGF in the aforementioned cell lines and to downregulate the expression of the $V E G F, h$ TERT and $c-M y c$ genes, the two latter involved in the control of the activation of telomerase. One of the synthetic stilbenes, $(E)$-4-(4-methoxystyryl)aniline, showed strong cytotoxicity and proved able to cause a marked decrease both in the secretion of VEGF and in the expression of the $h$-TERT and $c-M y c$ genes, in all cases at concentrations in the low nanomolar range.
\end{abstract}

\section{KEYWORDS}

resveratrol, stilbenes, VEGF, gene regulation, telomerase, $h T E R T, c-M y c$. 


\section{Introduction}

Resveratrol, a natural compound belonging to the class of stilbenes (Fig. 1) is a polyphenolic compound which occurs in grapes, red wine, chocolate, and certain berries and roots. It became popular since the 1993 paper on its inhibitory effects against the oxidation of human low-density lipoproteins, a chemical event at the onset of the pathogenesis of atherosclerosis [1]. In later years, further important biological features were reported for the compound, most particularly antioxidant, anticarcinogenic, and anti-inflammatory properties [2]. These properties were related to the ability of the compound to retard the onset of age-related diseases [3] and to its beneficial effect on other ailments such as viral attacks [4], diabetes [5], inflammation [6] and neurodegenerative diseases [7]. In addition, resveratrol has been shown to display, among other features: a) cancer chemopreventive effects by means of inhibiting the initiation step of the carcinogenesis process [8]; b) anticancer activity through inhibition of cell cycle progression and induction of apoptotic cell death [9]; and c) antiangiogenic activity with sufficient potency to suppress FGF-2 and VEGF-induced neovascularisation in vivo [10] and to inhibit bovine aorta endothelial cell proliferation, migration and tube formation in vitro [11].

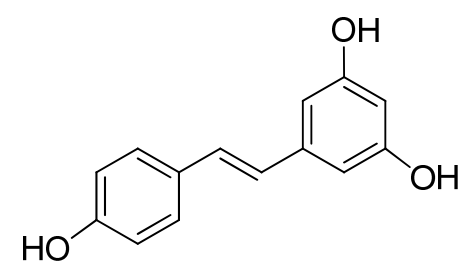

Figure 1. Structure of resveratrol

Tumor angiogenesis is a very complex process and involves the tight interplay of many factors [12]. Vascular endothelial growth factor (VEGF) is an inducer of angiogenesis and promotes endothelial cell survival, proliferation and migration while increasing vascular permeability [13]. In fact, overexpression in the production of VEGF has been reported to occur in various types of tumors [14]. Not unexpectedly, VEGF has become one further key target molecule in cancer therapy $[15,16]$.

Cancer cells are able to evolve the ability to overcome senescence upon telomerase reactivation [17]. This enzyme has been detected in about $90 \%$ of all malignant tumors [18], so that drugs with ability to inhibit telomerase activity are potentially useful weapons in the fight against cancer, aging and other diseases related to premature telomere shortening [19]. Recently, it has been reported that resveratrol downregulates the telomerase activity of MCF-7 cells and the nuclear levels of hTERT, the reverse transcriptase subunit of the telomerase complex [20]. 


\section{Research purpose}

When aiming at a more efficient anticancer therapy, compounds exhibiting not only high cytotoxic activity but also the ability to suppress tumoral angiogenesis and the expression of genes related to telomerase activation would be highly desirable [21]. On our ongoing research on anticancer properties of synthetic analogues derived from natural products, we have recently reported on the inhibition of VEGF formation in cancer cells and on endothelial cell differentiation promoted by synthetic stilbene derivatives [22]. Our study has established that resveratrol and several stilbene derivatives lead to a decrease in the production of VEGF by HT-29 cells. In view of these precedents we decided to evaluate the influence of new synthetic stilbene analogues not only on VEGF production, but also on the expression of the $h T E R T$ gene, involved in the process of telomerase activation. In addition, we further decided to measure the inhibition of expression of $c-M y c$, an oncogene which encodes the c-Myc protein that acts as a transcription factor for $h T E R T$ expression.

The structures of the synthetic resveratrol analogues which are the subject of this work are depicted in Figure 2. These compounds belong to two types: one corresponds to stilbenes carrying hydroxy and/or methoxy groups ( $a$-series in Figure 2$)$, whereas the other ( $b$-series) includes stilbenes carrying amine or amide functions in one of the rings, as well as hydroxyl or methoxy groups in the other.

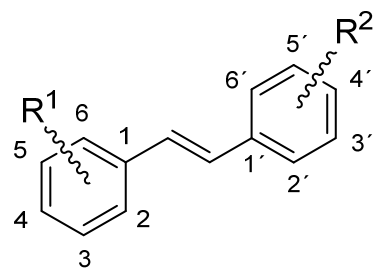
1a $\mathrm{R}^{1}=2-\mathrm{OH} \quad \mathrm{R}^{2}=2^{\prime}-\mathrm{OH}$
2a $\mathrm{R}^{1}=3-\mathrm{OH} \quad \mathrm{R}^{2}=2^{\prime}-\mathrm{OH}$
3a $\mathrm{R}^{1}=4-\mathrm{OH} \quad \mathrm{R}^{2}=2^{\prime}-\mathrm{OH}$
4a $\mathrm{R}^{1}=3-\mathrm{OH} \quad \mathrm{R}^{2}=3^{\prime}-\mathrm{OH}$
5a $\mathrm{R}^{1}=4-\mathrm{OH} \quad \mathrm{R}^{2}=3^{\prime}-\mathrm{OH}$
1b $\mathrm{R}^{1}=2-\mathrm{NH}_{2} \mathrm{R}^{2}=\mathrm{H}$
2b $\mathrm{R}^{1}=3-\mathrm{NH}_{2} \mathrm{R}^{2}=\mathrm{H}$
3b $\mathrm{R}^{1}=4-\mathrm{NH}_{2} \mathrm{R}^{2}=\mathrm{H}$
4b $\mathrm{R}^{1}=2-\mathrm{NH}_{2} \mathrm{R}^{2}=2^{\prime}-\mathrm{OH}$
5 b $\mathrm{R}^{1}=2-\mathrm{NH}_{2} \mathrm{R}^{2}=3^{\prime}-\mathrm{OH}$
6b $\mathrm{R}^{1}=2-\mathrm{NH}_{2} \mathrm{R}^{2}=4^{\prime}-\mathrm{OH}$
7b $\mathrm{R}^{1}=3-\mathrm{NH}_{2} \mathrm{R}^{2}=2^{\prime}-\mathrm{OH}$
8b $\mathrm{R}^{1}=3-\mathrm{NH}_{2} \mathrm{R}^{2}=3^{\prime}-\mathrm{OH}$
6a $\mathrm{R}^{1}=4-\mathrm{OH} \quad \mathrm{R}^{2}=4^{\prime}-\mathrm{OH}$
7 a $\mathrm{R}^{1}=2-\mathrm{OMe} \mathrm{R}^{2}=2^{\prime}-\mathrm{OH}$
8a $\mathrm{R}^{1}=3-\mathrm{OMe} \mathrm{R}^{2}=2^{\prime}-\mathrm{OH}$
9a $\mathrm{R}^{1}=4-\mathrm{OMe} \mathrm{R}^{2}=2^{\prime}-\mathrm{OH}$
10a $R^{1}=2-\mathrm{OMe} \mathrm{R}^{2}=3^{\prime}-\mathrm{OH}$
9b $\mathrm{R}^{1}=3-\mathrm{NH}_{2} \quad \mathrm{R}^{2}=4^{\prime}-\mathrm{OH}$
10b $\mathrm{R}^{1}=4-\mathrm{NH}_{2} \quad \mathrm{R}^{2}=2^{\prime}-\mathrm{OH}$
11b $\mathrm{R}^{1}=4-\mathrm{NH}_{2} \quad \mathrm{R}^{2}=3^{\prime}-\mathrm{OH}$
12b $\mathrm{R}^{1}=4-\mathrm{NH}_{2} \quad \mathrm{R}^{2}=4^{\prime}-\mathrm{OH}$
13b $\mathrm{R}^{1}=2-\mathrm{NH}_{2} \quad \mathrm{R}^{2}=2^{\prime}-\mathrm{OMe}$
14b $\mathrm{R}^{1}=2-\mathrm{NH}_{2} \quad \mathrm{R}^{2}=3^{\prime}-\mathrm{OMe}$
15b $\mathrm{R}^{1}=2-\mathrm{NH}_{2} \quad \mathrm{R}^{2}=4^{\prime}-\mathrm{OMe}$
16b $R^{1}=3-\mathrm{NH}_{2} \quad \mathrm{R}^{2}=2^{\prime}-\mathrm{OMe}$
11a $R^{1}=3-O M e ~ R^{2}=3^{\prime}-O H$
12a $R^{1}=4-\mathrm{OMe} \mathrm{R}^{2}=3^{\prime}-\mathrm{OH}$
13a $R^{1}=2-\mathrm{OMe} \mathrm{R}^{2}=4^{\prime}-\mathrm{OH}$
14a $\mathrm{R}^{1}=3-\mathrm{OMe} \mathrm{R}^{2}=4^{\prime}-\mathrm{OH}$
15a $R^{1}=4-\mathrm{OMe} R^{2}=4^{\prime}-\mathrm{OH}$
17b $\mathrm{R}^{1}=3-\mathrm{NH}_{2} \quad \mathrm{R}^{2}=3^{\prime}-\mathrm{OMe}$
18b $\mathrm{R}^{1}=3-\mathrm{NH}_{2} \quad \mathrm{R}^{2}=4^{\prime}-\mathrm{OMe}$
19b $\mathrm{R}^{1}=4-\mathrm{NH}_{2} \quad \mathrm{R}^{2}=2^{\prime}-\mathrm{OMe}$
20b $\mathrm{R}^{1}=4-\mathrm{NH}_{2} \quad \mathrm{R}^{2}=3^{\prime}-\mathrm{OMe}$
21b $\mathrm{R}^{1}=4-\mathrm{NH}_{2} \quad \mathrm{R}^{2}=4^{\prime}-\mathrm{OMe}$
22b $\mathrm{R}^{1}=2-\mathrm{NHCO}\left(\mathrm{CH}_{2}\right)_{10} \mathrm{Me} \mathrm{R}^{2}=\mathrm{H}$
23b $\mathrm{R}^{1}=3-\mathrm{NHCO}\left(\mathrm{CH}_{2}\right)_{10} \mathrm{Me} \mathrm{R}^{2}=\mathrm{H}$
24b $\mathrm{R}^{1}=4-\mathrm{NHCO}\left(\mathrm{CH}_{2}\right)_{10} \mathrm{Me} \quad \mathrm{R}^{2}=\mathrm{H}$

Figure 2. Structures of synthetic resveratrol analogues. 


\section{Synthetic work}

Stilbene derivatives 1a-15a were prepared by means of palladium-catalyzed Heck-type cross coupling reactions [23]. Monohydroxylated styrenes were used as the nucleophilic partners whereas hydroxy or methoxy bromobenzenes played the role of the electrophilic components, with $\operatorname{Pd}\left(\mathrm{PPh}_{3}\right)_{4}$ being the catalyst [24] (conditions A in Scheme 1). These reactions were performed under microwave irradiation, as these conditions have often been found to accelerate this kind of coupling reactions [25] (for details and yields, see Experimental section).

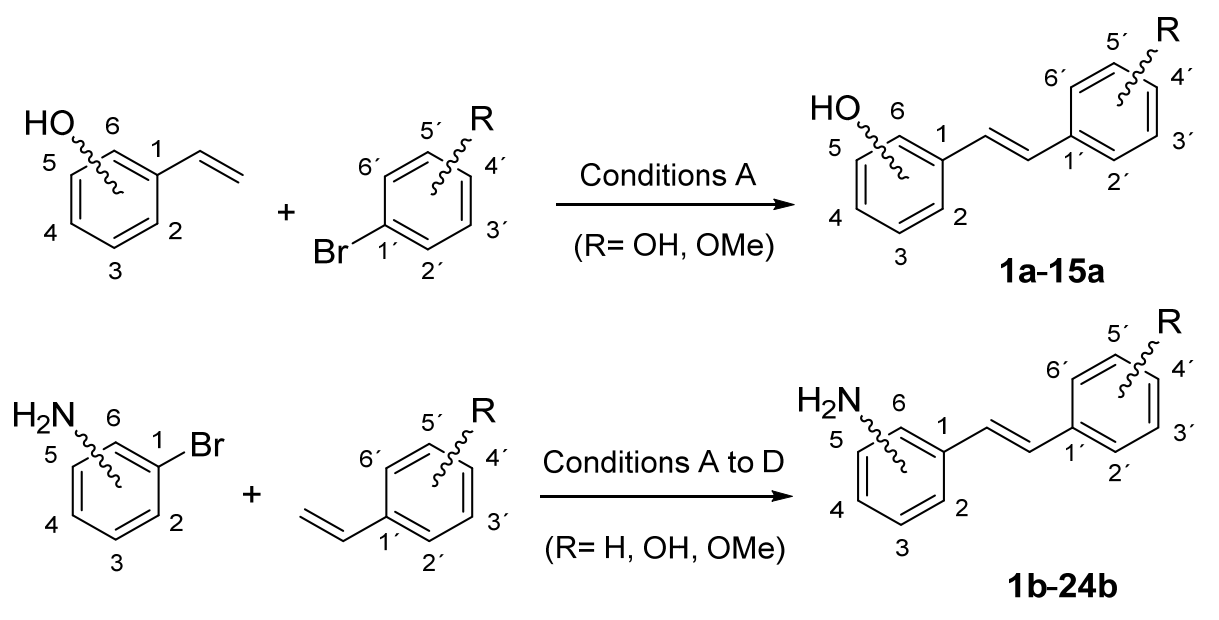

Scheme 1. Synthesis of stilbene derivatives by means of palladium-catalyzed Heck couplings (for more detailed descriptions of the reaction conditions and yields, see Supporting Information).

Preparation of compounds belonging to the $b$-series was also carried out with Heck-type cross coupling reactions. The same type of nucleophilic partners as above were used, with the electrophilic components being now bromoanilines. The aforementioned reaction conditions A, however, used in the synthesis of compounds of the $a$-series, were successful in the preparation of some compounds (e. g. $\mathbf{4 b}, \mathbf{5 b}, \mathbf{7 b}, \mathbf{9 b}$ ), but proved inefficient in other cases or else failed completely. In order to obtain the remaining amino stilbenes without protection of the amino groups, we undertook a survey of catalysts and conditions which resulted in three new reactions conditions, B, C and D (Scheme 1). In this case, $\mathrm{Pd}\left(\mathrm{NH}_{3}\right)_{2} \mathrm{Cl}_{2}$ was the catalyst [26], the differences residing in the reaction conditions. All Heck reactions were highly stereoselective and afforded, after chromatographic purification, the corresponding stilbenes of $E$-configuration with no traces of $Z$-isomers. Yields ranged from $50 \%$ to $88 \%$ and, most importantly, no protection/deprotection steps were needed.

Amides 22b-24b were prepared with the aim at observing whether the introduction of a lipophilic side chain would cause visible changes in the biological properties. Amide 23b was synthesized upon 
coupling compound $\mathbf{2 b}$ with dodecanoic acid in the presence of chlorosulfonyl isocyanate [27].

Attempts at preparing $\mathbf{2 2} \mathbf{b}$ and $\mathbf{2 4 b}$ in the same way by means of acylation of $\mathbf{1 b}$ and $\mathbf{3 b}$, respectively, were unsatisfactory. Thus, $\mathbf{2 2 b}$ and $\mathbf{2 4 b}$ were obtained by first acylating the corresponding bromoaniline followed by Heck coupling of the resulting amide with styrene under conditions $\mathrm{C}$.

\section{Biological work}

\subsection{Inhibition of cell proliferation}

We carried out a measurement of the cytotoxic activity of our synthetic stilbenes using two tumoral cells, the human colon HT-29 and the breast adenocarcinoma MCF-7 cell lines, as well as one non tumoral cell line, the human embryonic kidney cell line, HEK-293 [28]. Table 1 shows cytotoxicity values for stilbenes of the $a$-series, expressed as the compound concentration $(\mu \mathrm{g} / \mathrm{mL})$ that causes $50 \%$ inhibition of cell growth $\left(\mathrm{IC}_{50}\right)$. Table 1 further shows the $\alpha$ and $\beta$ coefficients, obtained by dividing the $\mathrm{IC}_{50}$ values of the normal cell line by those of either the HT-29 or the MCF-7 cell line, respectively (see footnote in Table 1). The higher the value of either coefficient, the higher the therapeutic safety margin of the compound in the corresponding cell line.

Table 1. $\mathrm{IC}_{50}$ values $(\mu \mathrm{g} / \mathrm{mL})$ and selectivity coefficients for compounds of the $a$-series.

\begin{tabular}{clllll} 
Compound & HT-29 & MCF-7 & HEK-293 & $\boldsymbol{\alpha}^{\mathbf{b}}$ & $\boldsymbol{\beta}^{\mathbf{c}}$ \\
\hline Resveratrol & $34.1 \pm 1.4$ & $16.1 \pm 1.1$ & $7.1 \pm 1.0$ & 0.2 & 0.4 \\
1a & $25 \pm 7$ & $23.0 \pm 1.3$ & $24.3 \pm 2.3$ & 0.9 & 1.1 \\
$\mathbf{2 a}$ & $27 \pm 7$ & $20.1 \pm 2.1$ & $18 \pm 8$ & 0.7 & 0.9 \\
$\mathbf{3 a}$ & $22 \pm 9$ & $21 \pm 3$ & $17.5 \pm 1.5$ & 0.8 & 0.8 \\
4a & $25.9 \pm 1.0$ & $21 \pm 6$ & $21 \pm 5$ & 0.8 & 1 \\
$\mathbf{5 a}$ & $6.9 \pm 1.9$ & $23 \pm 3$ & $1.1 \pm 0.7$ & 0.2 & $<0.1$ \\
$\mathbf{6 a}$ & $>100$ & $6.8 \pm 0.2$ & $1.2 \pm 0.1$ & $<0.1$ & 0.2 \\
$\mathbf{7 a}$ & $23 \pm 6$ & $17.9 \pm 2.4$ & $15.0 \pm 2.5$ & 0.7 & 0.8 \\
$\mathbf{8 a}$ & $26 \pm 3$ & $18 \pm 4$ & $20 \pm 4$ & 0.8 & 1.1 \\
$\mathbf{9 a}$ & $10 \pm 4$ & $17 \pm 6$ & $21 \pm 4$ & 2.1 & 1.2 \\
$\mathbf{1 0 a}$ & $17 \pm 4$ & $24.3 \pm 1.0$ & $24 \pm 3$ & 1.4 & 1 \\
$\mathbf{1 1 a}$ & $11.5 \pm 3$ & $13 \pm 3$ & $19 \pm 7$ & 1.6 & 1.5 \\
$\mathbf{1 2 a}$ & $22 \pm 4$ & $21 \pm 5$ & $24 \pm 3$ & 1.1 & 1.1 \\
$\mathbf{1 3 a}$ & $24 \pm 3$ & $19 \pm 4$ & $41 \pm 3$ & 1.7 & 2.2 \\
$\mathbf{1 4 a}$ & $26 \pm 4$ & $21.0 \pm 1.5$ & $24 \pm 3$ & 0.9 & 1.1
\end{tabular}


$15 \mathbf{a}$

$17.4 \pm 0.2$

$11.3 \pm 2.3$

$3.9 \pm 0.5$

0.2

0.3

${ }^{a}$ Values are the average ( \pm s.d.) of three different measurements performed as described in the Material and Methods section. ${ }^{\mathrm{b}} \alpha=\mathrm{IC}_{50}$ (HEK-293) / IC $\mathrm{I}_{50}$ (HT-29). ${ }^{\mathrm{c}} \beta=\mathrm{IC}_{50}(\mathrm{HEK}-293) / \mathrm{IC}_{50}(\mathrm{MCF}-7)$. Values of $\alpha$ and $\beta$ have been rounded off to a decimal figure.

The observed values for $\mathrm{IC}_{50}$ are in the low to medium micromolar range, with compound $\mathbf{5 a}$ showing the lowest values in the HT-29 cell line and compound 6a showing the lowest values in the MCF-7 cell line. In the case of HT-29 cell lines, all synthetic compounds exhibit better $\mathrm{IC}_{50}$ values than resveratrol. As regards the $\alpha$ and $\beta$ coefficients, the calculated values are is most cases close to, or even lower than 1 . This means that the cytotoxic activity of these compounds is similar in both the non tumoral and the tumoral line.

Table 2. $\mathrm{IC}_{50}$ values $(\mu \mathrm{g} / \mathrm{mL})$ and selectivity coefficients for compounds of the $b$-series.

\begin{tabular}{clllcc} 
Compound & HT-29 & MCF-7 & HEK-293 & $\boldsymbol{\alpha}^{\mathbf{b}}$ & $\boldsymbol{\beta}^{\mathbf{c}}$ \\
\hline Resveratrol & $34.1 \pm 1.4$ & $16.1 \pm 1.1$ & $7.1 \pm 1.0$ & 0.2 & 0.4 \\
$\mathbf{1 b}$ & $17 \pm 4$ & $1.4 \pm 0.1$ & $1.3 \pm 0.2$ & 0.1 & 0.9 \\
$\mathbf{2 b}$ & $12.9 \pm 0.9$ & $14 \pm 4$ & $84 \pm 11$ & 6.5 & 6 \\
$\mathbf{3 b}$ & $4.4 \pm 1.1$ & $16 \pm 0.1$ & $11.4 \pm 0.4$ & 2.6 & 0.7 \\
$\mathbf{4 b}$ & $36 \pm 5$ & $39 \pm 3$ & $27 \pm 7$ & 0.7 & 0.7 \\
$\mathbf{5 b}$ & $30 \pm 5$ & $17 \pm 3$ & $20 \pm 7$ & 0.7 & 1.2 \\
$\mathbf{6 b}$ & $>100$ & $79 \pm 3$ & $7 \pm 3$ & $<0.1$ & $<0.1$ \\
$\mathbf{7 b}$ & $30.4 \pm 1.8$ & $24.7 \pm 0.2$ & $96 \pm 15$ & 3.2 & 3.9 \\
$\mathbf{8 b}$ & $43 \pm 16$ & $54 \pm 7$ & $>100$ & 2.3 & 1.8 \\
$\mathbf{9 b}$ & $51 \pm 16$ & $6 \pm 3$ & $7 \pm 3$ & 0.1 & 1.2 \\
$\mathbf{1 0 b}$ & $37 \pm 5$ & $23 \pm 4$ & $21.4 \pm 1.4$ & 0.6 & 1 \\
$\mathbf{1 1 b}$ & $42 \pm 6$ & $24.8 \pm 0.4$ & $25 \pm 8$ & 0.6 & 1 \\
$\mathbf{1 2 b}$ & $30.6 \pm 2.4$ & $2.2 \pm 0.4$ & $0.8 \pm 0.1$ & 0.03 & 0.4 \\
$\mathbf{1 3 b}$ & $>100$ & $>100$ & $2.1 \pm 0.7$ & $<0.1$ & $<0.1$ \\
$\mathbf{1 4 b}$ & $21.2 \pm 1.5$ & $6.1 \pm 1.8$ & $0.5 \pm 0.1$ & $<0.1$ & $<0.1$ \\
$\mathbf{1 5 b}$ & $73 \pm 5$ & $0.4 \pm 0.1$ & $0.6 \pm 0.1$ & $<0.1$ & 1.4 \\
$\mathbf{1 6 b}$ & $25.3 \pm 0.1$ & $38.7 \pm 0.6$ & $45 \pm 0.3$ & 1.8 & 1.2 \\
$\mathbf{1 7 b}$ & $19.6 \pm 2.0$ & $34 \pm 5$ & $16 \pm 5$ & 0.8 & 0.5 \\
$\mathbf{1 8 b}$ & $16.3 \pm 0.4$ & $23 \pm 4$ & $11 \pm 0.3$ & 0.7 & 0.5 \\
$\mathbf{1 9 b}$ & $22 \pm 4$ & $3.2 \pm 1.7$ & $1 \pm 0.3$ & $<0.1$ & 0.3 \\
$\mathbf{2 0 b}$ & $16.1 \pm 0.1$ & $52 \pm 6$ & $18 \pm 4$ & 1.1 & 0.3 \\
$\mathbf{2 1 b}$ & $0.0036 \pm 0.0015$ & $0.0021 \pm 0.0005$ & $0.012 \pm 0.004$ & 3.4 & 5.7 \\
$\mathbf{2 2 b}$ & $2.5 \pm 0.7$ & $12 \pm 0.9$ & $16 \pm 9$ & 6.4 & 1.3
\end{tabular}


${ }^{a}$ Values are the average ( \pm s.d.) of three different measurements performed as described in the Material and Methods section. ${ }^{\mathrm{b}} \alpha=\mathrm{IC}_{50}$ (HEK-293) / $\mathrm{IC}_{50}$ (HT-29). ${ }^{\mathrm{c}} \beta=\mathrm{IC}_{50}(\mathrm{HEK}-293) / \mathrm{IC}_{50}(\mathrm{MCF}-7)$. Values of $\alpha$ and $\beta$ have been rounded off to a decimal figure.

Cytotoxicity values for stilbenes of the $b$-series are shown in Table 2, with most compounds showing cytotoxicities of the same order of magnitude as those of Table 1. It can be further observed that the introduction of the aliphatic side chains (compounds $\mathbf{2 2 b} \mathbf{2}-\mathbf{2 4 b}$ ) did not cause improvements in the cytotoxic activities. However, one of the stilbene derivatives calls for attention: compound $\mathbf{2 1 b}$ showed cytotoxic values in the low nanomolar range for both cancer cell lines. The $\alpha$ and $\beta$ coefficients, clearly above 1 , further show that the compound is noticeably more cytotoxic for tumoral cell lines than for normal ones, a desirable feature.

\subsection{Effect of stilbene derivatives on VEGF protein secretion and VEGF gene inhibition}

The action of stilbene derivatives on VEGF secretion and VEGF gene inhibition was conducted on the HT-29 tumoral cell line. For these measurements compounds $9 \mathbf{a}-\mathbf{1 3 a}, \mathbf{2 b}, \mathbf{3 b}, \mathbf{7 b}, \mathbf{8 b}, \mathbf{1 6}$ b and 20b22b were selected because they had $\alpha$-coefficients above 1 . In addition, compounds $\mathbf{1 b}, \mathbf{1 4 b}, \mathbf{1 7 b}$ and $\mathbf{1 8 b}$ were further selected because they had lower $\mathrm{IC}_{50}$ values than resveratrol.

The secretion of the vascular endothelial growth factor (VEGF) was first determined by means of the ELISA procedure [29], as described in the Experimental Section. Results for all the selected compounds (except 21b, which will be discussed later) are depicted in Figure 3, which shows the percentage of VEGF secreted to the culture medium after $72 \mathrm{~h}$ of incubation in the presence of DMSO (control experiment) and in the presence of each of the compounds investigated at a concentration of 10 $\mu \mathrm{g} / \mathrm{mL}$ (lower than their $\mathrm{IC}_{50}$ values). 


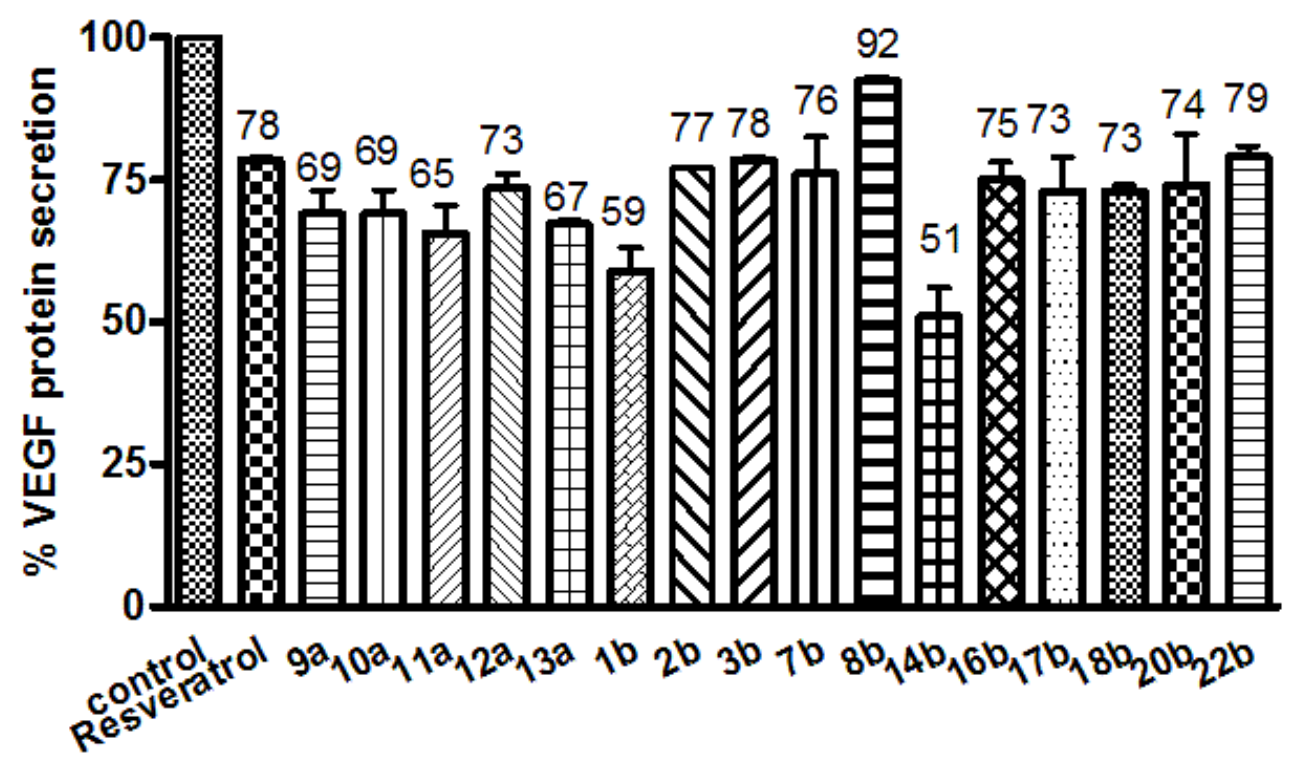

Figure 3. VEGF protein secretion from HT-29 cells determined by means of the ELISA procedure. At least three measurements were performed in each case. Concentration of all compounds was $10 \mu \mathrm{g} / \mathrm{mL}$. Bars represent mean values of VEGF secretion (percentage values related to control) and error bars indicate standard errors of the mean. The statistical significance was evaluated using one-sample t-tests $(\mathrm{P}<0.001)$.

While the majority of the compounds showed an inhibitory effect on VEGF production, the values were very similar to that of resveratrol, which reduced VEGF secretion to $78 \%$ of the control value. The most active is compound $\mathbf{1 4 b}$, which causes a decrease to $51 \%$.

The high cytotoxicity of compound $\mathbf{2 1 b}$, as compared with the remaining stilbenes, justified a separate study. It was evaluated as regards inhibition of VEGF production on both the HT-29 and the MCF-7 cell line (Figure 4). When a concentration of $1 \mathrm{ng} / \mathrm{mL}$ was used, no noticeable effect on VEGF production was detected in either of the two cell lines. However, at $2 \mathrm{ng} / \mathrm{mL}$ concentration, compound 21b inhibited VEGF secretion to $84 \%$ of the control value in the case of HT-29 cells and to $75 \%$ in the case of MCF-7. When HT-29 cells were cultivated in the presence of $3 \mathrm{ng} / \mathrm{mL}$ of compound $\mathbf{2 1} \mathbf{b}$, VEGF protein secretion further dropped to $59 \%$. These values are similar to that achieved by resveratrol at a concentration of $10 \mu \mathrm{g} / \mathrm{mL}$. Compound $\mathbf{2 1 b}$ therefore is three orders of magnitude more active than resveratrol in inhibiting VEGF production. 


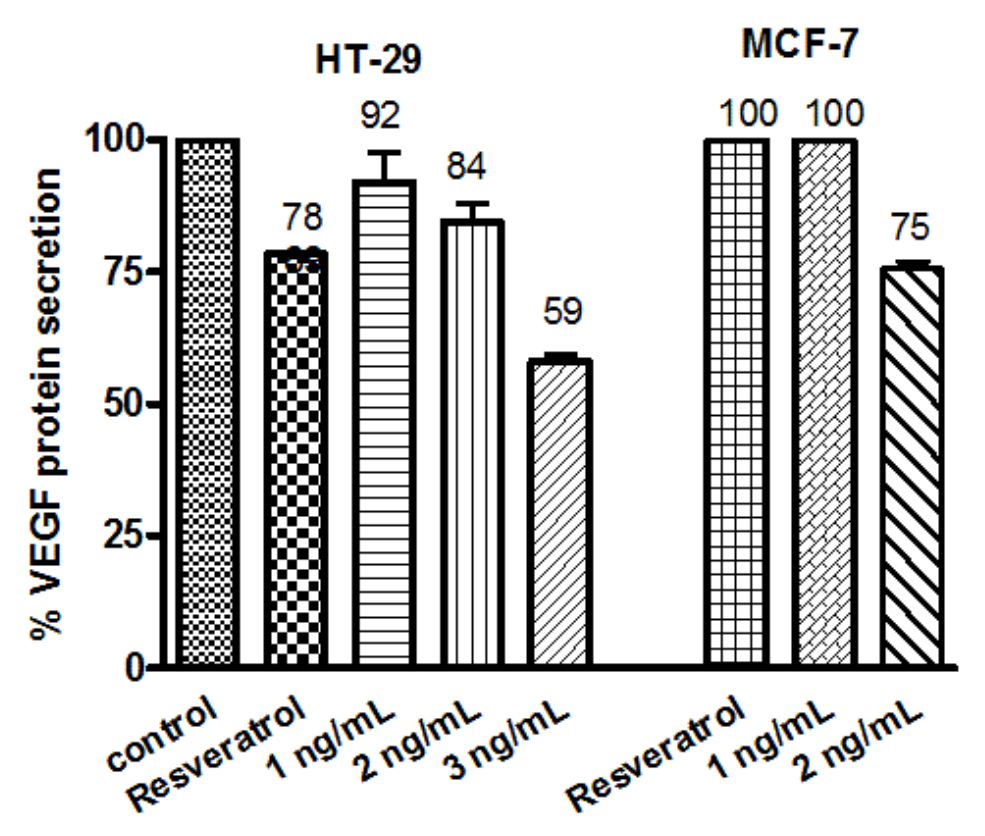

Figure 4. VEGF protein secretion from HT-29 and MCF-7 cells with compound $\mathbf{2 1 b}$ as determined by means of the RT-qPCR methodology. At least three measurements were performed in each case. Concentration of resveratrol was $10 \mu \mathrm{g} / \mathrm{mL}$. Bars represent mean values of VEGF secretion (percentage values related to control) and error bars indicate standard errors of the mean. The statistical significance was evaluated using one-sample t-tests $(\mathrm{P}<0.001)$.

While the results depicted in Figures 3 and 4 point out that the investigated compounds cause inhibition of the VEGF production, they do not permit conclusions about the precise phase of the VEGF generation process with which they interfere. In order to further investigate the mechanism of action of the compounds under study, we proceeded to determine whether they were able to control protein production at the transcriptional level. The VEGF production we have determined with the ELISA procedure is that secreted to the culture medium and corresponds mainly to the lighter VEGFA165 isoform [30]. Therefore, in order to evaluate the ability of our compounds to inhibit the expression of the $V E G F$ gene, we incubated HT-29 cells for $48 \mathrm{~h}$ with several selected stilbene derivatives at a concentration of $10 \mu \mathrm{g} / \mathrm{mL}$, again with DMSO as the control test. For that purpose, the reverse transcription quantitative PCR (RT-qPCR) methodology [31] was used as described in the Experimental Section. Results for all the selected compounds (except 21b) are shown in Figure 5 as percentage of the $V E G F$ gene expression. All values were standardized (100\%) to control (DMSO) and to $\beta$-actine. 


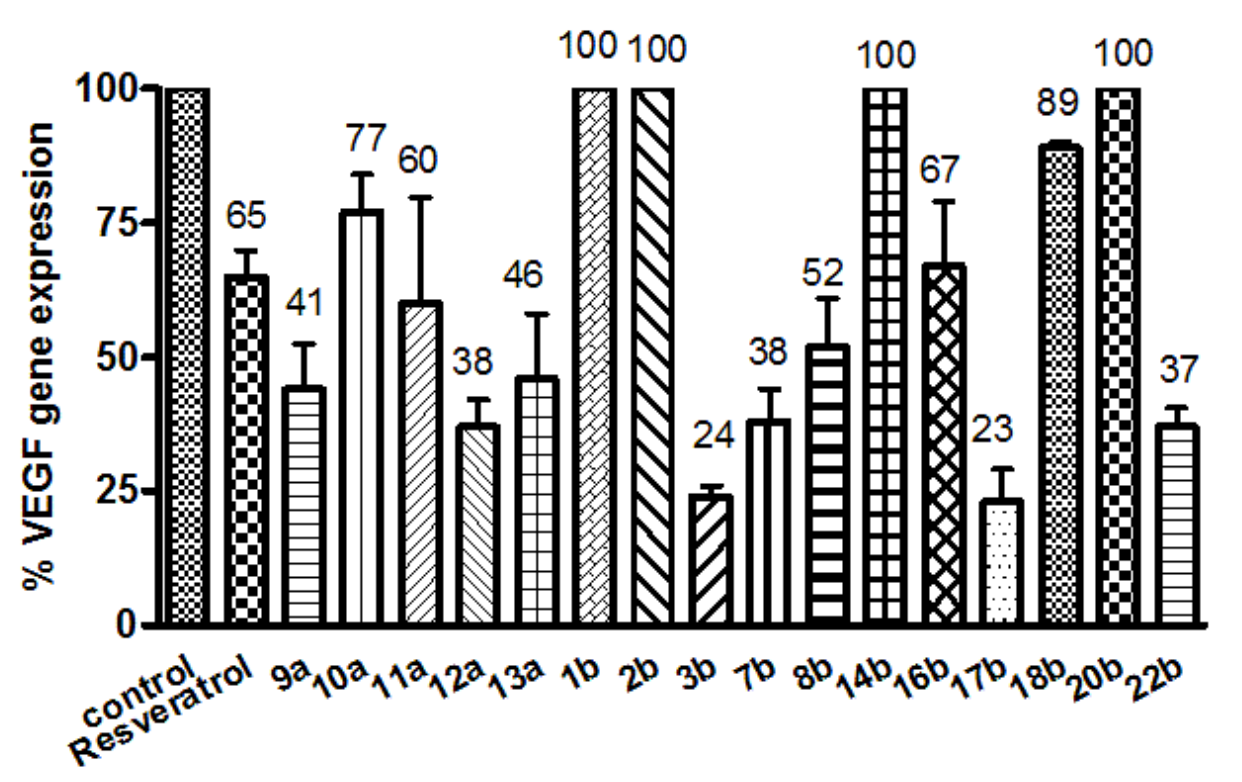

Figure 5. Expression percentage of the $V E G F$ gene after $48 \mathrm{~h}$ of incubation of HT-29 cells determined by means of the RT-qPCR methodology. At least three measurements were performed in each case. Concentration of all compounds was $10 \mu \mathrm{g} / \mathrm{mL}$. Error bars indicate standard errors of the mean. The statistical significance was evaluated using one-sample t-tests $(\mathrm{P}<0.001)$.

Comparison of Fig. 5 with Fig. 4 reveals much more meaningful differences in activity between the compounds investigated. Thus, several compounds showed a visibly stronger inhibitory effect on the transcription of VEGF mRNA than resveratrol, which lowered $V E G F$ gene expression to $65 \%$ of the control value. The reduction degrees were particularly strong for compounds $\mathbf{3 b}$ and $\mathbf{1 7} \mathbf{b}$, which caused inhibition of the gene expression to $24 \%$ and $23 \%$, respectively, of the control value.

The results displayed in Figs. 4 and 5 do not show correlation between the VEGF amount excreted to the medium and the degree of gene expression. Compounds $\mathbf{3 b}$ and $\mathbf{1 7} \mathbf{b}$, for instance, proved highly effective in the inhibition of the $V E G F$ gene expression but much less so in decreasing the amount of VEGF secreted to the medium. This suggests that these compounds exert the control of VEGF production at a phase different from that of gene transcription, perhaps during the post-translational stage, during which the lighter isoforms such as VEGFA-165 are formed and secreted to the medium [30].

As in the previous case, a separate study was performed for compound $\mathbf{2 1 \mathbf { b }}$. The inhibition of the $V E G F$ gene expression was measured in this case on both HT-29 and MCF-7 cancer cell lines, the results being depicted in Figure 6. When HT-29 cells were incubated in the presence of 1, 2 or $3 \mathrm{ng} / \mathrm{mL}$ of compound $\mathbf{2 1 b}$, the level of $V E G F$ gene expression was similar to that achieved with resveratrol at a 
concentration of $10 \mu \mathrm{g} / \mathrm{mL}$ In other words, the potency of compound $\mathbf{2 1 b}$ in downregulating $V E G F$ gene expression is three orders of magnitude higher than that of resveratrol. In addition, when MCF-7 cells were treated with $2 \mathrm{ng} / \mathrm{mL}$ of compound $\mathbf{2 1 b}$, only $36 \%$ of VEGF gene expression was detected. Thus, compound $\mathbf{2 1 b}$ is about 5000 times more active than resveratrol.

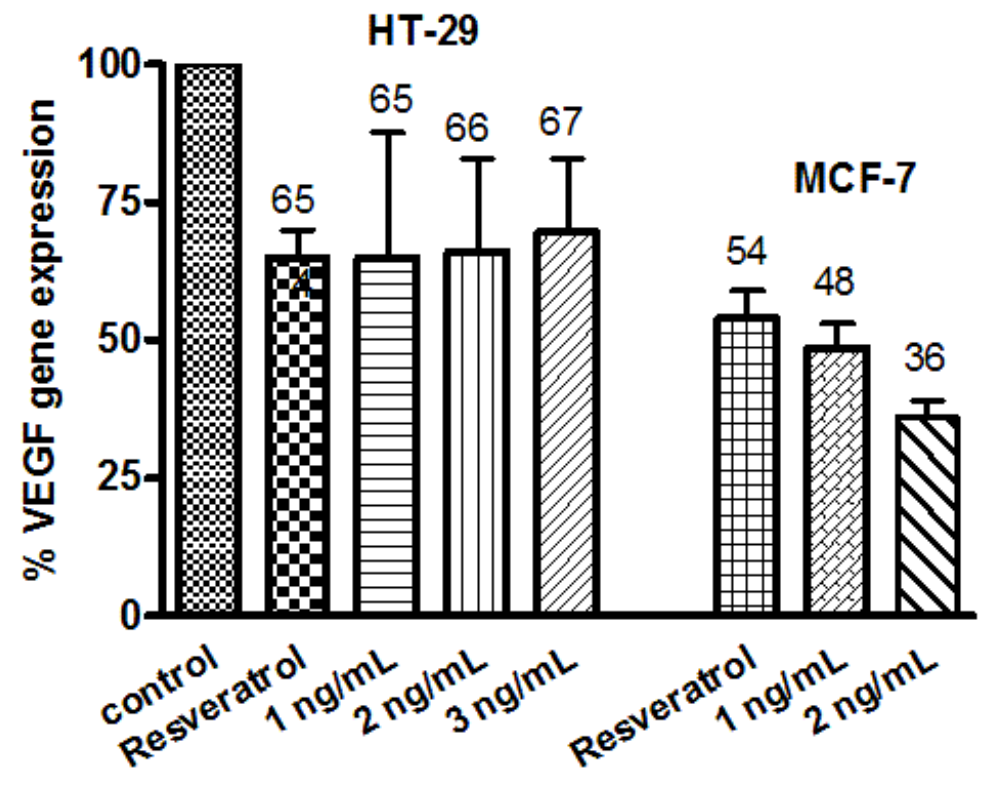

Figure 6. Expression percentage of the $V E G F$ gene after $48 \mathrm{~h}$ of incubation of HT-29 and MCF-7 cells with compound $\mathbf{2 1 b}$ as determined by means of the RT-qPCR methodology. At least three measurements were performed in each case. Concentration of resveratrol was $10 \mu \mathrm{g} / \mathrm{mL}$. Error bars indicate standard errors of the mean. The statistical significance was evaluated using one-sample ttests $(\mathrm{P}<0.001)$.

\subsection{Effect of stilbene derivatives on the inhibition of the hTERT and c-Myc genes}

Human telomerase contains an RNA component (hTERC) that serves as a template for the addition of the repeat nucleotide sequences and also a reverse transcriptase subunit (hTERT) which catalyzes the nucleotide polymerization process. In addition, there are other associated protein factors, the role of which has not yet been completely elucidated. Human telomerase is regulated during development and differentiation, mainly through transcriptional control of the $h T E R T$ gene, the expression of which is restricted to cells that exhibit telomerase activity. This indicates that the hTERT subunit is the rate limiting factor of the enzyme complex. For the expression of the $h T E R T$ gene, several transcriptional factors such as c-Myc, a proto-oncoprotein [32], have been found to play an important role through 
upregulation of the mRNA encoding the hTERT protein subunit [33]. Thus, and as an initial study of the potential activity of these stilbene derivatives as inhibitors of telomerase activation, we have investigated their ability to inhibit the expression of the $h T E R T$ and $c-M y c$ genes, which are responsible for the production of the corresponding proteins.

In order to determine whether the studied compounds were able to regulate the expression of the two aforementioned genes, we have performed a RT-qPCR analysis using again HT-29 tumoral cells. The cells were incubated for $48 \mathrm{~h}$ in the presence of DMSO (control) and $10 \mu \mathrm{g} / \mathrm{mL}$ of each of the studied compounds (lower than the $\mathrm{IC}_{50}$ values). Results are depicted in Fig. 7 ( $h T E R T$ gene expression) and Fig. 8 (c-Myc gene expression). As in previous experiments, the highly cytotoxic compound $\mathbf{2 1 b}$ was the subject of a separate study, which will be described below.

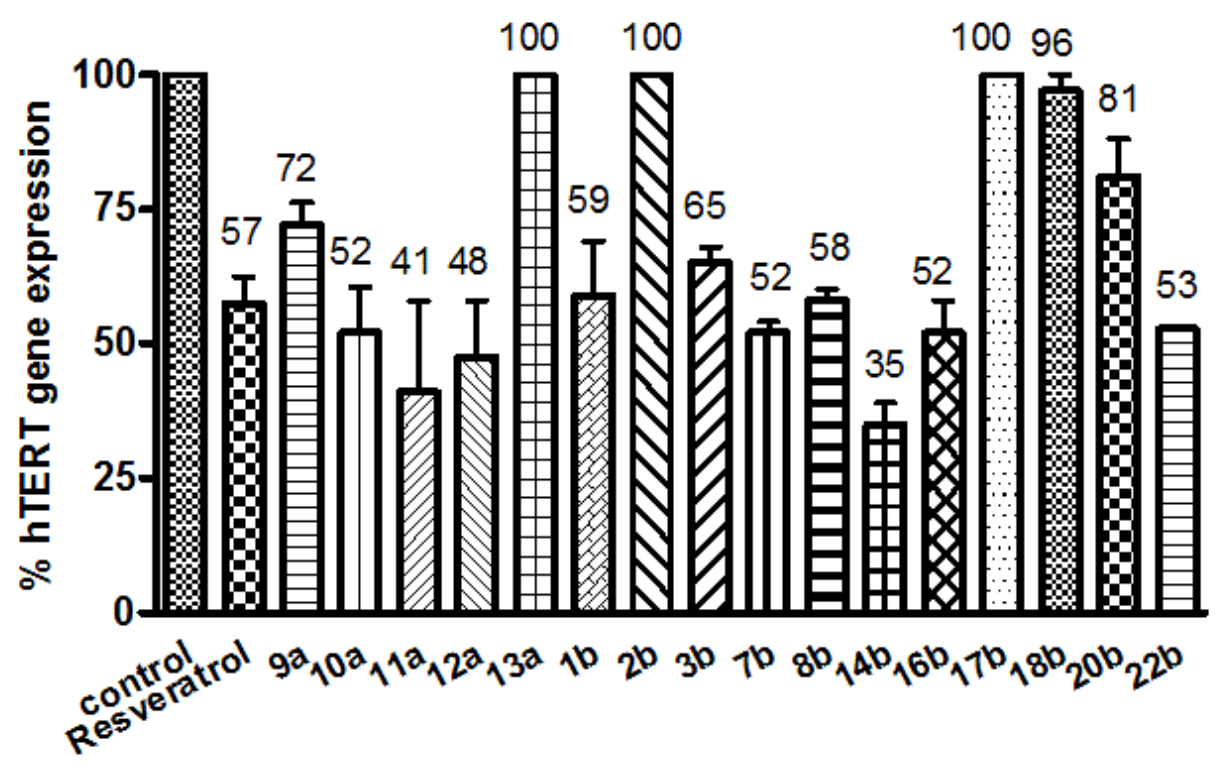

Figure 7. Expression percentage of the hTERT gene after $48 \mathrm{~h}$ of incubation with HT-29 cells as determined by means of the RT-qPCR methodology. At least three measurements were performed in each case. Concentration of all compounds was $10 \mu \mathrm{g} / \mathrm{mL}$. Bars represent mean values of VEGF secretion (percentage values related to control) and error bars indicate standard errors of the mean. The statistical significance was evaluated using one-sample t-tests $(\mathrm{P}<0.001)$. 


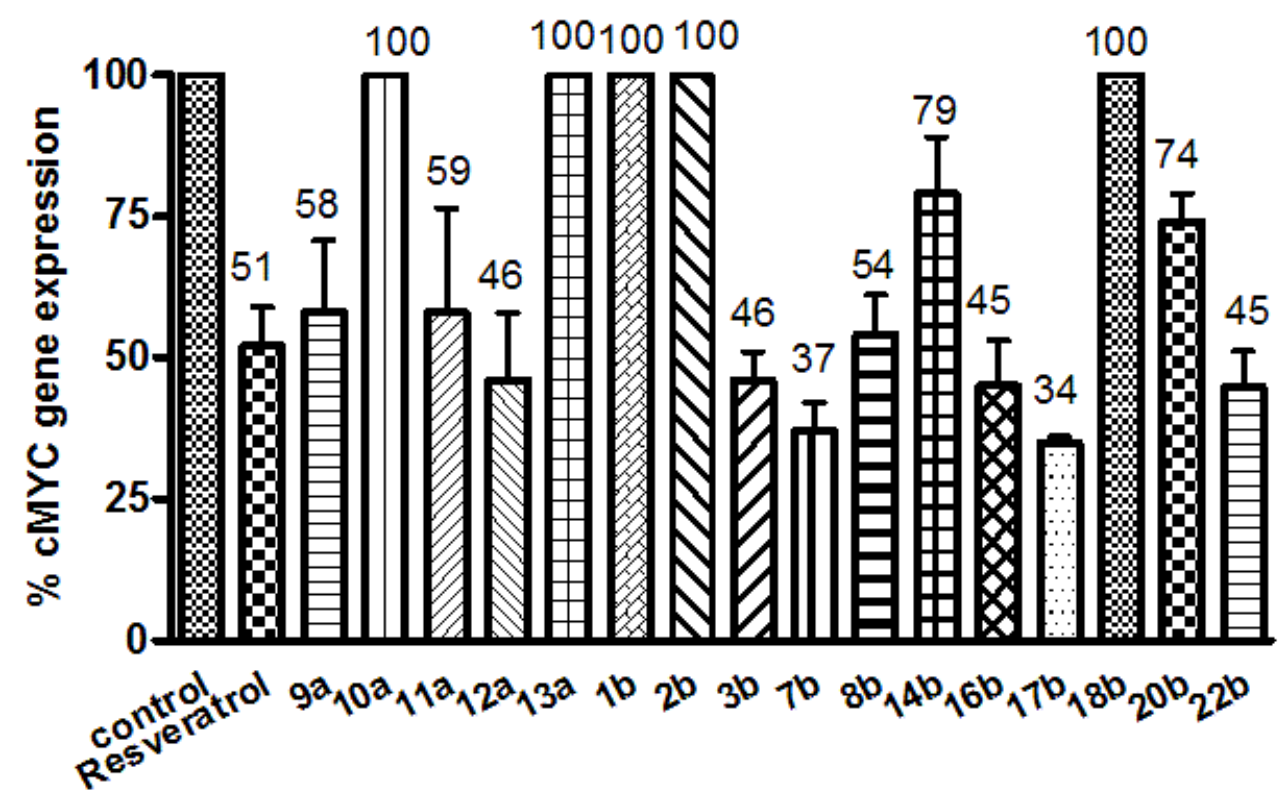

Figure 8. Expression percentage of the $c-M y c$ gene after $48 \mathrm{~h}$ of incubation with HT-29 cells as determined by means of the RT-qPCR methodology. At least three measurements were performed in each case. Concentration of all compounds was $10 \mu \mathrm{g} / \mathrm{mL}$. Bars represent mean values of VEGF secretion (percentage values related to control) and error bars indicate standard errors of the mean. The statistical significance was evaluated using one-sample t-tests $(\mathrm{P}<0.001)$.

As shown in Fig. 7, compounds 10a-12a, 3b, 7b, 14b, 16b and 22b showed the highest ability to downregulate the expression of the hTERT gene, their activities being somewhat higher than that of resveratrol. As regards the expression of the $c-M y c$ gene (Fig. 8), more or less the same compounds showed the highest inhibitory activity. In any case, however, differences in activity with resveratrol were perceptible but not particularly worth noting.

Inhibition of $h-T E R T$ and $c-M y c$ gene expression for compound 21b was measured on both HT-29 and MCF-7 cancer cell lines. Results are shown in Figs. 9 and 10, which show that compound 21b was able to downregulate the expression of the $h$-TERT and $c-M y c$ genes. The expression of the $h$-TERT gene was decreased to $48 \%$ of the control value when $3 \mathrm{ng} / \mathrm{mL}$ concentration was used on HT-29 cells, and to $51 \%$ when $2 \mathrm{ng} / \mathrm{mL}$ concentration was used on MCF-7 cells. Again, the potency of compound 21b in downregulating the $h-T E R T$ and $c-M y c$ genes is 3000-5000 times greater than that of resveratrol. 


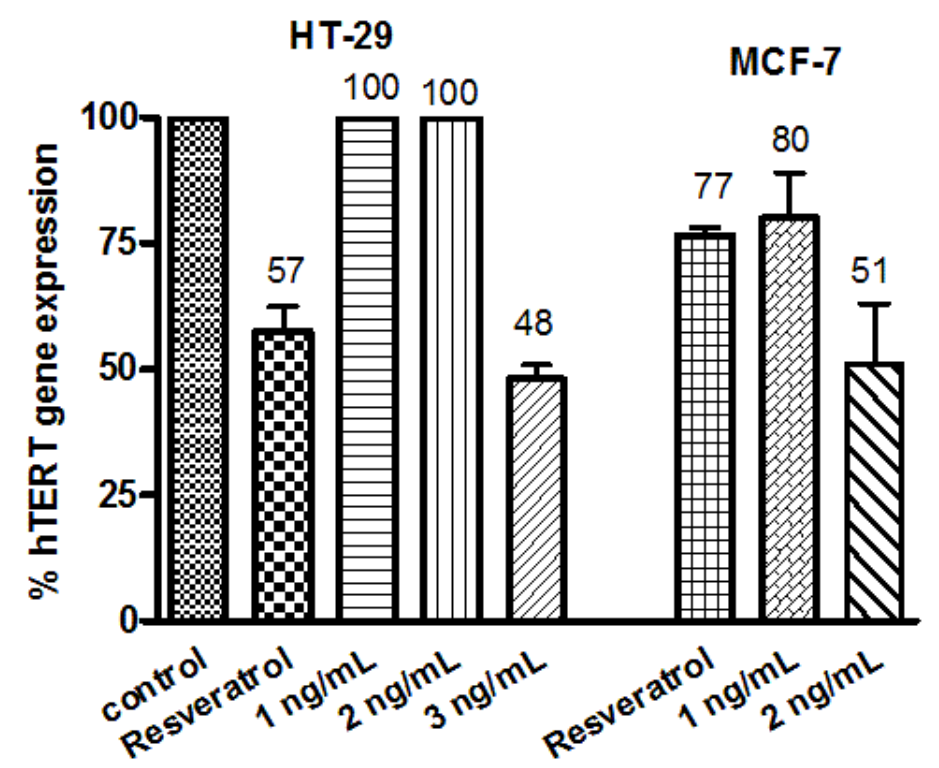

Figure 9. Expression percentage of the $h T E R T$ gene after $48 \mathrm{~h}$ of incubation with compound $\mathbf{2 1 b}$ as determined by means of the RT-qPCR methodology. At least three measurements were performed in each case. Concentration of resveratrol was $10 \mu \mathrm{g} / \mathrm{mL}$. Bars represent mean values of VEGF secretion (percentage values related to control) and error bars indicate standard errors of the mean. The statistical significance was evaluated using one-sample t-tests $(\mathrm{P}<0.001)$.

\section{HT-29}

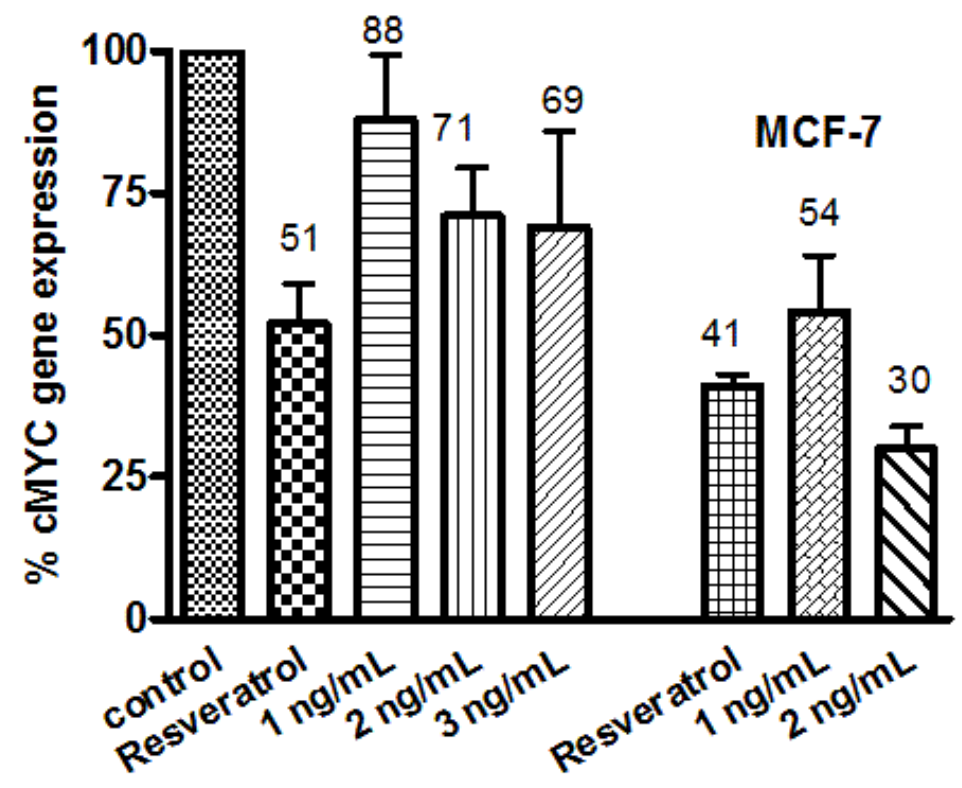

Figure 10. Expression percentage of the $c-M y c$ gene after $48 \mathrm{~h}$ of incubation of HT-29 and MCF-7 cells with compound $\mathbf{2 1 b}$ as determined by means of the RT-qPCR methodology. At least three measurements were performed in each case. Concentration of resveratrol was $10 \mu \mathrm{g} / \mathrm{mL}$. Bars represent 
mean values of VEGF secretion (percentage values related to control) and error bars indicate standard errors of the mean. The statistical significance was evaluated using one-sample t-tests $(\mathrm{P}<0.001)$.

Table 3 summarizes the results observed for the synthetic compounds $\mathbf{1 2 a}, \mathbf{3 b}, \mathbf{7 b}, \mathbf{1 4 b}, \mathbf{1 6} \mathbf{b}, \mathbf{1 7} \mathbf{b}$, 21b and 22b, as well as for resveratrol. As regards inhibition of the expression of the VEGF, $h T E R T$ and $c-M y c$ genes, stilbene derivatives bearing amino groups ( $b$-series) feature much better than those lacking them ( $a$-series). Within stilbenes carrying an amide function, the most active is compound $\mathbf{2 2 b}$ whereas within amino stilbenes, those having a methoxy group $(\mathbf{1 4 b}, \mathbf{1 6 b}, \mathbf{1 7 b}$ and $\mathbf{2 1 b})$ perform better

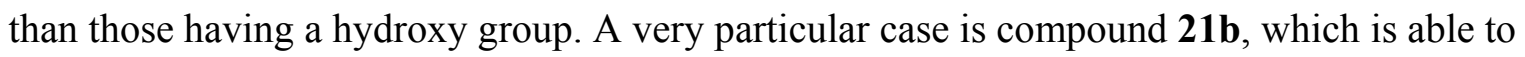
downregulate the secretion of VEGF protein and the expression of $V E G F, h-T E R T$ and $c-M y c$ genes at concentrations in the low nanomolar level.

Table 3. Compared percentages of excretion of the VEGF protein and of the expression of the $V E G F$, hTERT and $c-M y c$ genes. ${ }^{\mathrm{a}}$

\begin{tabular}{|c|c|c|c|c|c|}
\hline Compd & $\begin{array}{l}\text { Cytotoxicity } \\
\left(\mathrm{IC}_{50}, \mu \mathrm{g} / \mathrm{mL}\right)\end{array}$ & $\begin{array}{l}\% \text { Secretion of } \\
\text { VEGF protein }\end{array}$ & $\begin{array}{l}\% \text { Expression } \\
\text { of } V E G F \text { gene }\end{array}$ & $\begin{array}{l}\% \text { Expression } \\
\text { of } h T E R T \text { gene }\end{array}$ & $\begin{array}{l}\% \text { Expression } \\
\text { of } c-M y c \text { gene }\end{array}$ \\
\hline Resv. & $34.1 \pm 1.4$ & 78 & 65 & 57 & 51 \\
\hline $12 a$ & $22 \pm 4$ & 73 & 38 & 48 & 46 \\
\hline $3 \mathbf{b}$ & $4.4 \pm 1.1$ & 78 & 24 & 65 & 46 \\
\hline $7 b$ & $30.4 \pm 1.8$ & 76 & 38 & 52 & 37 \\
\hline $14 \mathrm{~b}$ & $21.2 \pm 1.5$ & 51 & 100 & 35 & 79 \\
\hline $16 \mathrm{~b}$ & $25.3 \pm 1$ & 75 & 67 & 52 & 45 \\
\hline $17 b$ & $19.6 \pm 2$ & 73 & 23 & 100 & 34 \\
\hline $21 b^{b}$ & $0.0036 \pm 0.001$ & 59 & 67 & 48 & 69 \\
\hline $22 b$ & $2.5 \pm 0.7$ & 79 & 37 & 53 & 45 \\
\hline
\end{tabular}

${ }^{a}$ All values refer to HT-29 cells. The values observed for the control (DMSO without added drugs) are taken as the $100 \%$ reference of protein excretion or gene expression. Therefore, the lower the value, the higher the activity of the drug in the corresponding activity. Except for $\mathbf{2 1 b}$, measurements were performed at concentration values of $10 \mu \mathrm{g} / \mathrm{mL}$.

${ }^{\mathrm{b}}$ At a concentration of $3 \mathrm{ng} / \mathrm{mL}$.

The biological activities of resveratrol are often ascribed, at least in part, to its antioxidant activity. The various biological activities of resveratrol analogues depend upon the number and location of the 
hydroxy groups [34], minor structural changes in such stilbenes having major effects on their biological activity [35]. In the present study, a series of 39 stilbenes carrying hydroxy, methoxy and amino groups were compared with resveratrol for their cytotoxicity and for their ability to inhibit VEGF secretion and the expression of the VEGF, $h-T E R T$ and $c-M y c$ genes. Several compounds were found to be more active than resveratrol, the case of (E)-4-(4-methoxystyryl)aniline (21b) being particularly interesting because of its high cytotoxicity. In order to find some relationships between chemical structure and biological activity, we have graphically represented $\alpha$ coefficients vs. $\beta$ coefficients of the studied compounds (Fig. 11). Figs. 11a to 11c display the $\alpha$ and $\beta$ values for stilbenes carrying an ortho-, metaand para-hydroxy group, respectively. Figure $11 \mathrm{~d}$ shows values for the remaining compounds.
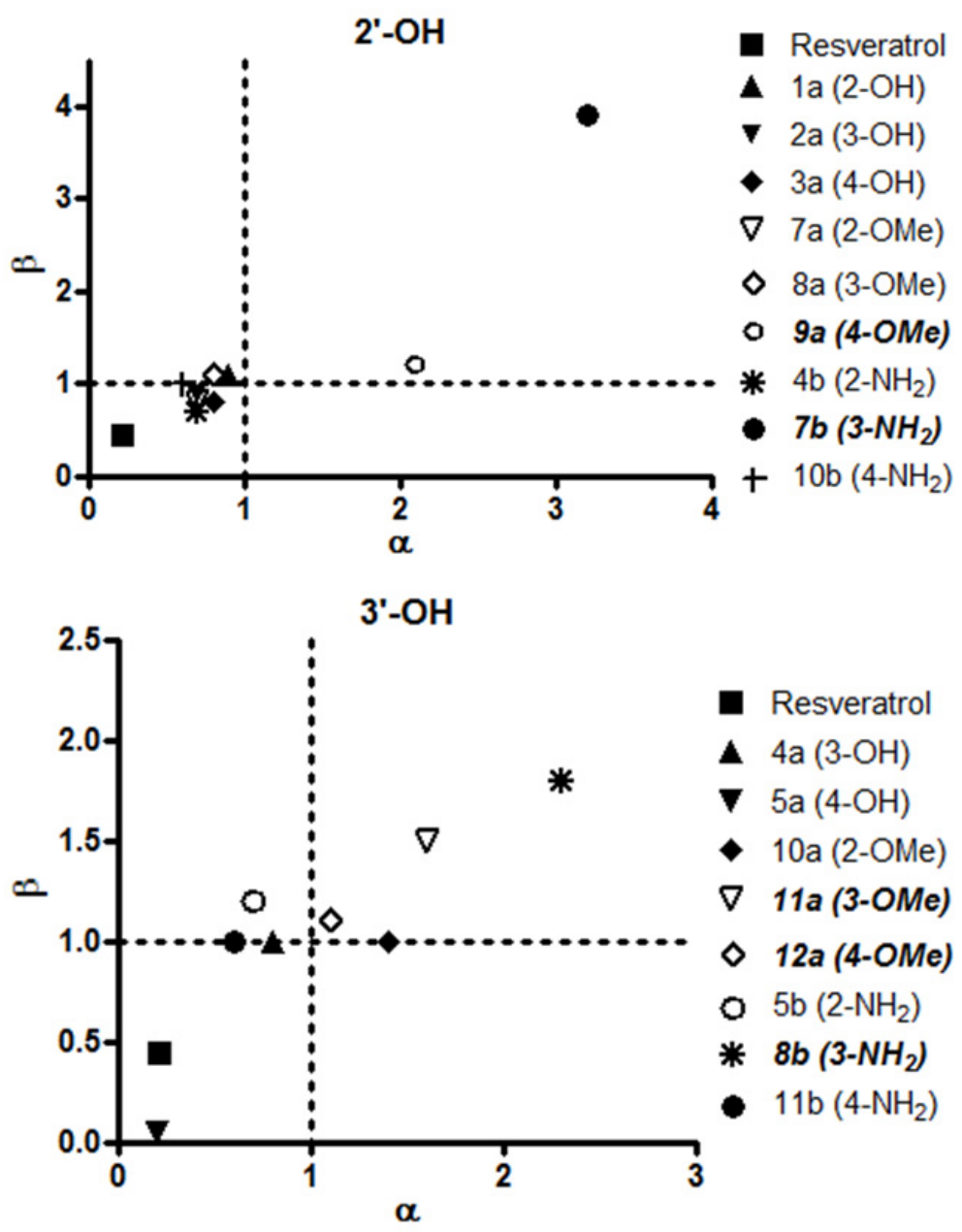

Figure 11. $\alpha$ coefficients vs. $\beta$ coefficients of the synthetic stilbenes. 

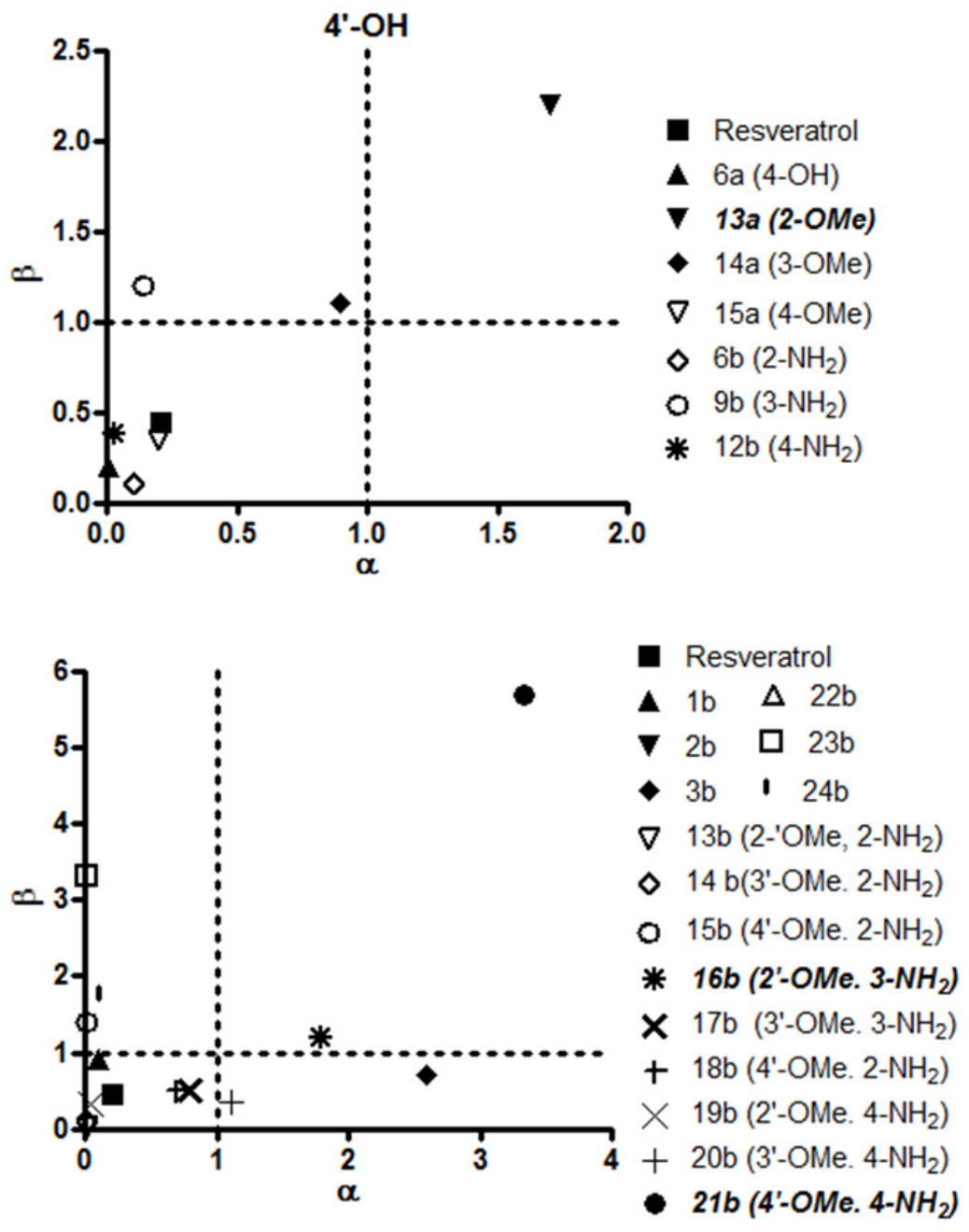

Figure 11 (cont.). $\alpha$ coefficients vs. $\beta$ coefficients of the synthetic stilbenes.

As mentioned above, the higher the coefficient values, the better the safety margin for the corresponding compound from the therapeutic point of view. Aside from compound $\mathbf{2 1 b}$, which is three orders of magnitude more cytotoxic than the others, the best safety margins are achieved with compounds 9a (2'-OH, 4-OMe), 13a (4'-OH, 2-OMe), 7b (2'-OH, 3-NH $)$, 8b (3'-OH, 3- $\left.\mathrm{NH}_{2}\right)$ and 16b (2'-OMe, 3-NH $\mathrm{NH}_{2}$. These three amino stilbenes share in common an amino group in meta position, regardless of the position occupied by the hydroxy or methoxy group. Compound $\mathbf{2 1 b}$, however, which is cytotoxic at nanomolar level and shows the highest safety margins, has its amino group in the para position. This may possibly indicate that, in comparison with the rest of compounds, $\mathbf{2 1 b}$ shows a different mode of action. 
In Figure 12, the percentage of VEFG protein secretion is graphically represented vs. the percentage of $h$-TERT gene expression. Compounds $\mathbf{1 4 b}$ and $\mathbf{2 1 b}$ are located in the lower left quadrant, where high inhibition of VEGF secretion and high inhibition of $h$-TERT gene expression are combined. It is worth noting that this desirable dual mode of action is exhibited by compound $\mathbf{2 1 b}$ at low nanomolar concentrations, whereas compound $\mathbf{1 4 b}$ achieves it only at the micromolar level.

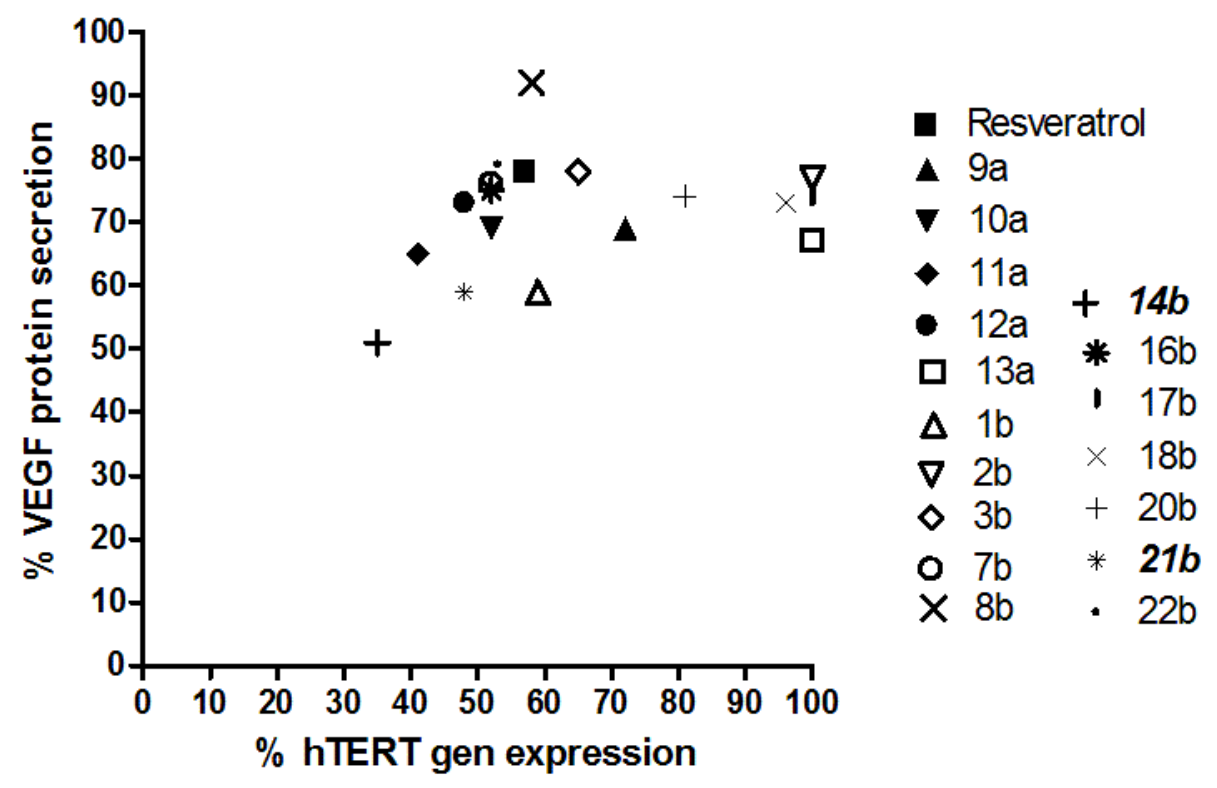

Figure 12. Percentage of VEFG protein secretion vs. percentage of $h$-TERT gene expression.

\section{Summary and conclusions}

In conclusion, 39 stilbene derivatives have been synthesized and evaluated for their biological activity. One of them, (E)-4-(4-methoxystyryl)aniline (compound 21b) has proven particularly interesting. Not only has this compound a strong cytotoxicity at the low nanomolar level and a good safety margin, it further combines these features with an ability to inhibit VEFG protein secretion and the expression of the telomerase related $h-T E R T$ and $c-M y c$ genes at similarly low concentrations. Compound 21b therefore may possibly display anticancer activity through a multiple mode of action. It is worth noting that $\mathbf{2 1 b}$ shows an extremely high difference in activity with all other compounds, including its positional isomers $\mathbf{1 9 b}$ and $\mathbf{2 0 b}$, and its demethyl derivative $\mathbf{1 2 b}$. This may possibly suggest that its interactions with its (still unknown) biomolecular targets, and perhaps also the targets themselves, are of a different nature. More studies will be required to acquire a knowledge about its mechanism of action. 


\section{Experimental}

\subsection{Chemistry. General procedures}

The general reaction conditions and the physical and spectral data of all synthetic intermediates and final compounds are described in detail in the Supporting Information. The samples of compounds used for the biological studies were purified to $>95 \%$ by means of preparative HPLC.

\subsection{Biological studies. Materials and methods}

\subsubsection{Reagents and cell culture}

Cell culture media were purchased from Gibco (Grand Island, NY, USA). Fetal bovine serum (FBS) was a product of Harlan-Seralab (Belton, U.K.). Supplements and other chemicals not listed in this section were obtained from Sigma Chemicals Co. (St. Louis, Mo., USA). Plastics for cell culture were supplied by Thermo Scientific ${ }^{\mathrm{TM}}$ BioLite. All tested compounds were dissolved in DMSO at a concentration of $10 \mu \mathrm{g} / \mathrm{mL}$ and stored at $-20^{\circ} \mathrm{C}$ until use.

Cell lines were maintained in Dulbecco's modified Eagle's medium (DMEM) containing glucose (1 $\mathrm{g} / \mathrm{L})$, glutamine $(2 \mathrm{mM})$, penicillin $(50 \mathrm{IU} / \mathrm{mL})$, streptomycin $(50 \mu \mathrm{g} / \mathrm{mL})$ and amphoterycin $(1.25$ $\mu \mathrm{g} / \mathrm{mL})$, supplemented with $10 \%$ FBS.

\subsubsection{Cytotoxicity assays}

The 3-(4,5-dimethylthiazol-2-yl)-2,5-diphenyltetrazolium bromide (MTT; Sigma Chemical Co., St. Louis, MO) dye reduction assay in 96-well microplates was used, as previously described [36]. Some 5 x $10^{3}$ cells of HT-29, MCF-7 or HEK-293 cells in a total volume of $100 \mu \mathrm{L}$ of their respective growth media were incubated with serial dilutions of the tested compounds. After 3 days of incubation $\left(37^{\circ} \mathrm{C}\right.$, $5 \% \mathrm{CO}_{2}$ in a humid atmosphere), $10 \mu \mathrm{l}$ of MTT ( $5 \mathrm{mg} / \mathrm{ml}$ in PBS) were added to each well and the plate was incubated for further $4 \mathrm{~h}\left(37^{\circ} \mathrm{C}\right)$. The resulting formazan was dissolved in $150 \mu \mathrm{L}$ of $0.04 \mathrm{~N}$ $\mathrm{HCl} / 2$-propanol and read at $550 \mathrm{~nm}$. All determinations were carried out in triplicate.

\subsubsection{ELISA analysis}

HT-29 cells at 70-80\% confluence were collected after serum starvation for $24 \mathrm{~h}$. Cells were incubated with the selected stilbene derivatives in DMSO for $72 \mathrm{~h}$ (Fig. 3). Culture supernatants were collected and VEGF secreted by HT-29 cells was determined using Invitrogen Human Vascular Endothelial Growth Factor ELISA Kit according to the manufacturer's instructions. 


\subsubsection{RT-qPCR analysis}

HT-29 cells at 70-80\% confluence were collected after serum starvation for $24 \mathrm{~h}$. Cells were incubated with $10 \mu \mathrm{g} / \mathrm{mL}$ of the corresponding drugs in DMSO for $48 \mathrm{~h}$. Cells were collected and the total cellular RNA from HT-29 cells was isolated using Ambion RNA extraction Kit according to the manufacturer's instructions. The cDNA was synthesized by MMLV-RT with 1-21 $\mu \mathrm{g}$ of extracted RNA and oligo(dT)15 according to the manufacturer's instructions.

Amplification of the genes was performed by use of a StepOnePlus ${ }^{\mathrm{TM}}$ thermalcycler. Fast TaqMan Gene Expression Master Mix containing the appropriate buffer for the amplification conditions, dNTPs, thermostable DNA polymerase enzyme and a passive reference probe was used. Each of the genes were amplified using predesigned primers by Life Technologies TaqMan ${ }^{\circledR}$ Gene Expression Assays, Hs99999903-m1 ( $\beta$-actin), Hs00900055-m1 (VEGF), Hs00972646-m1 (hTERT) and Hs00153408-m1 (c-Myc).

\subsubsection{Statistical analysis}

Data are expressed as the mean \pm SEM. Statistical analyses were done using Microsoft Excel and GraphPad Prism ${ }^{\circledR}$. Differences between means were determined using Student's t-Test or one-way ANOVA with Dunnett's Multiple Comparison Test, and considered to be statistically significant at $\mathrm{p} \leq 0.001$.

\section{Acknowledgments}

Financial support has been granted by the Spanish Government (MINECO, Ministerio de Economía y Competitividad, project CTQ2011-27560), by the Consellería d'Empresa, Universitat i Ciencia de la Generalitat Valenciana (projects PROMETEO/2013/027 and ACOMP/2014/272) and by the Universitat Jaume I (PI-1B-2011-37). R. M.-C. thanks the University Jaume I for a predoctoral fellowship.

\section{Supplementary Information}

Description of general features and reaction conditions. Spectral data and graphical NMR spectra of all new compounds. 


\section{References}

[1] E. N. Frankel, A. L. Waterhouse, J. E. Kinsella, Inhibition of human LDL oxidation by resveratrol, Lancet 341 (1993) 1103-1104.

[2] (a) J. Marchal, F. Pifferi, F. Aujard, Resveratrol in mammals: effects on aging biomarkers, agerelated diseases, and life span, Ann. N. Y. Acad. Sci. 1290 (2013) 67-73.

(b) R. S. Yao, X. Q. Lu, Q. X. Guan, L. Zheng, X. Lu, B. F. Ruan, Synthesis and biological evaluation of some novel resveratrol amide derivatives as potential anti-tumor agents, Eur. J. Med. Chem. 62 (2013) 222-231.

(c) M. Miliovsky, I. Svinyarov, Y. Mitrev, Y. Evstatieva, D. Nikolova, M. Chochkova, M. G. Bogdanov, A novel one-pot synthesis and preliminary biological activity evaluation of cisrestricted polyhydroxy stilbenes incorporating protocatechuic acid and cinnamic acid fragments, Eur. J. Med. Chem. 66 (2013) 185-192.

(d) A. Csiszar, Anti-inflammatory effects of resveratrol: possible role in prevention of age-related cardiovascular disease, Ann. N. Y. Acad. Sci. 1215 (2011) 117-122.

[3] S. Quideau, D. Deffieux, L. Pouységu, Resveratrol Still Has Something To Say about Aging!, Angew. Chem. Int. Ed. 51 (2012) 6824-6826.

[4] V. Krishnan, S. L. Zeichner, Host cell gene expression during human immunodeficiency virus type I latency and reactivation and effects of targeting genes that are differentially expressed in viral latency, J. Virol. 78 (2004) 9458-9473.

[5] P. J. Elliott, S. M. Walpole, L. Morelli, P. D. Lambert, W. Lunsmann, C. H. Westphal, S. Lavu, Resveratrol/SRT501 Sirtuin SIRT1 Activator Treatment of Type 2 Diabetes, Drugs Fut. 34 (2009) 291-295.

[6] C. R. Pace-Asciak, S. Hahn, E. P. Diamandis, G. Soleas, D. M. Goldberg, The red wine phenolics trans-resveratrol and quercetin block human platelet-aggregation and eicosanoid synthesis implications for protection against coronary heart-disease, Clin. Chim. Acta 235 (1995) 207-219.

[7] J. A. Parker, M. Arango, S. Abderrahmane, E. Lambert, C. Tourette, H. Catoire, C. Neri, Resveratrol rescues mutant polyglutamine cytotoxicity in nematode and mammalian neurons, Nat. Genet. 37 (2005) 349-350.

[8] (a) M. S. Jang, E. N. Cai, G. O. Udeani, K. V. Slowing, C. F. Thomas, C. W. W. Beecher, H. H. S. Fong, N. R. Farnsworth, A. D. Kinghorn, R. G. Mehta, R. C. Moon, J. M. Pezzuto, Cancer chemopreventive activity of resveratrol, a natural product derived from grapes, Science 275 (1997) 218-220. 
(b) T. P. Kondratyuk, E.-J. Park, L. E. Marler, S. Y. Ahn, Y. Yuan, Y. S. Choi, R. Yu, R. B. van Breemen, B. Sun, J. Hoshino, M. Cushman, K. C. Jermihov, A. D. Mesecar, C. J. Grubbs, J. M. Pezzuto, Resveratrol derivatives as promising chemopreventive agents with improved potency and selectivity, Mol. Nutr. Food Res. 55 (2011) 1249-1265.

[9] D. Delmas, E. Solary, N. Latruffe, Resveratrol, a Phytochemical Inducer of Multiple Cell Death Pathways: Apoptosis, Autophagy and Mitotic Catastrophe, Curr. Med. Chem 18 (2011) 11001121.

[10] E. Brakenhielm, R. H. Cao, Y. H. Cao, Suppression of angiogenesis, tumor growth, and wound healing by resveratrol, a natural compound in red wine and grapes, FASEB J. 15 (2001) 17981800.

[11] K. Igura, T. Ohta, Y. Kuroda, K. Kaji, Resveratrol and quercetin inhibit angiogenesis in vitro, Cancer Lett. 171 (2001) 11-16.

[12] (a) N. Ferrara, VEGF: an update on biological and therapeutic aspects, Curr. Opin. Biotechnol. 11 (2000) 617-624.

(b) P. Carmeliet, R. K. Jain, Molecular mechanisms and clinical applications of angiogenesis, Nature 473 (2011) 298-307.

[13] S. M. Moghaddam, A. Amini, D. L. Morris, M. H. Pourgholami, Significance of vascular endothelial growth factor in growth and peritoneal dissemination of ovarian cancer, Cancer Metastasis Rev. 31 (2012) 143-162.

[14] (a) Z. P. Zhu, L. Witte, Inhibition of tumor growth and metastasis by targeting tumor-associated angiogenesis with antagonists to the receptors of vascular endothelial growth factor, Invest. New Drugs 17 (1999) 195-212.

(b) R. B. Caldwell, M. Bartoli, M. A. Behzadian, A. E. B. El-Remessy, M. Al-Shabrawey, D. H. Platt, G. I. Liou, R. W. Caldwell, Vascular endothelial growth factor and diabetic retinopathy: Role of oxidative stress, Curr. Drug Targets 6 (2005) 511-524.

(c) A. F. C. Okines, A. R. Reynolds, D. Cunningham, Targeting angiogenesis in esophagogastric adenocarcinoma, Oncologist 16 (2011) 844-858.

[15] For some relevant references, see, for example:

(a) M. Potente, H. Gerhardt, P. Carmeliet, Basic and therapeutic aspects of angiogenesis , Cell 146 (2011) 873-887.

(b) G. Korpanty, E. Smyth, Anti-VEGF Strategies - from antibodies to tyrosine kinase inhibitors: background and clinical development in human cancer, Curr. Pharm. Des. 18 (2012) 2680-2701. 
(c) A. G. Linkous, E. M. Yazlovitskaya, Novel therapeutic approaches for targeting tumor angiogenesis, Anticancer Res. 32 (2012) 1-12.

[16] Antiangiogenic therapies are not completely devoid of problems. See, for example: (a) A. R. Quesada, M. A. Medina, R. Muñoz-Chapuli, A. L. G. Ponce, Do not say ever never more: the ins and outs of antiangiogenic therapies, Curr. Pharm. Des. 16 (2010) 3932-3957.

(b) K. De Bock, M. Mazzone, P. Carmeliet, Antiangiogenic therapy, hypoxia, and metastasis: risky liaisons, or not?, Nature Rev. Clin. Oncol. 8 (2011) 393-404.

(c) L. Moserle, G. Jiménez-Valerio, O. Casanovas, Antiangiogenic therapies: going beyond their limits, Cancer Discov. 4 (2014) 31-41.

[17] (a) N. W. Kim, M. A. Piatyszek, K. R. Prowse, C. B. Harley, M. D. West, P. L. C. Ho, G. M. Coviello, W. E. Wright, S. L. Weinrich, J. W. Shay, Specific association of human telomerase activity with immortal cells and cancer, Science 266 (1994) 2011-2015.

(b) B.-S. Herbert, A. E. Pitts, S. I. Baker, S. E. Hamilton, W. E. Wright, J. W. Shay, D. R. Corey, Inhibition of human telomerase in immortal human cells leads to progressive telomere shortening and cell death, Proc. Natl. Acad. Sci. 96 (1999) 14276-14281.

[18] (a) J. W. Shay, W. E. Wright, Role of telomeres and telomerase in cancer, Semin. Cancer Biol. 21 (2011) 349-353.

(b) V. A. Zakian, Telomeres: the beginnings and ends of eukaryotic chromosomes, Exp. Cell Res. 318 (2012) 1456-1460.

[19] (a) K. A. Olaussen, K. Dubrana, J. Domont, J.-P. Spano, L. Sabatier, J.-C. Soria, Telomeres and telomerase as targets for anticancer drug development, Crit. Rev. Oncol. Hematol. 57 (2006) 191214.

(b) D. R. Corey, Telomeres and telomerase: from discovery to clinical trials, Chem. Biol. 16 (2009) 1219-1223.

(c) C. M. Buseman, W. E. Wright, J. W Shay, Is telomerase a viable target in cancer?, Mut. Res. 730 (2012) 90-97.

[20] G. Lanzilli, M. P. Fuggetta, M. Tricarico, A. Cottarelli, A, Serafino, R. Falchetti, G. Ravagnan, M. Turriziani, R. Adamo, O. Franzese, E. Bonmassar, Resveratrol down-regulates the growth and telomerase activity of breast cancer cells in vitro, Int. J. Oncol. 28 (2006) 641-648.

[21] See, for example: C.-T. Chen, M.-C. Hung, Beyond anti-VEGF: dual-targeting antiangiogenic and antiproliferative therapy, Am. J. Transl. Res. 5 (2013) 393-403. 
[22] R. Martí-Centelles, R. Cejudo-Marín, E. Falomir, J. Murga, M. Carda, J. A. Marco, Inhibition of VEGF expression in cancer cells and endothelial cell differentiation by synthetic stilbene derivatives, Bioorg. Med. Chem. 21 (2013) 3010-3015.

[23] (a) R. Heck, Palladium-catalyzed reactions of organic halides with olefins, Acc. Chem. Res. 12 (1979) 146-151.

(b) I. P. Beletskaya, A. V. Cheprakov, The Heck reaction as a sharpening stone of palladium catalysis, Chem. Rev. 100 (2000) 3009-3066.

(c) A. F. Schmidt, A. Al Halaiqa, V. V. Smirnov, Interplays between reactions within and without the catalytic cycle of the Heck reaction as a clue to the optimization of the synthetic protocol, Synlett (2006) 2861-2878.

[24] N. Sharma, D. Mohanakrishnan, A. Shard, A. Sharma, Saima, A. K. Sinha, D. Sahal, Stilbenechalcone hybrids: design, synthesis, and evaluation as a new class of antimalarial scaffolds that trigger cell death through stage specific apoptosis, J. Med. Chem. 55 (2012) 297-311.

[25] V. P. Mehta, E. V. Van der Eycken, Microwave-assisted C-C bond forming cross-coupling reactions: an overview, Chem. Soc. Rev. 40 (2011) 4925-4936.

[26] S.-H. Huang, J.-R. Chen, F.-Y. Tsai, Palladium(II)/cationic 2,2 '-bipyridyl system as a highly efficient and reusable catalyst for the Mizoroki-Heck reaction in water, Molecules 15 (2010) 315330.

[27] K. S. Keshavamurthy, Y. D. Vankar, D. N. Dhar, Preparation of acid anhydrides, amides, and esters using chlorosulfonyl isocyanate as a dehydrating agent, Synthesis (1982) 506-508.

[28] N. Arden, M. J. Betenbaugh, Life and death in mammalian cell culture: strategies for apoptosis inhibition, Trends Biotechnol. 22 (2004) 174-180.

[29] (a) B. K. Van Weemen, A. H. W. M. Schuurs, Immunoassay using antigen-enzyme conjugate, FEBS Lett. 15 (1971) 232-236.

(b) E. Engvall, P. Perlmann, Enzyme-linked immunosorbent assay, ELISA .3. quantitation of specific antibodies by enzyme-labeled anti-immunoglobulin in antigen-coated tubes, J. Immunol. 109 (1972) 129-135.

(c) A. J. O’Beirne, H. R. Cooper, Heterogeneous enzyme immunoassay, J. Hystochem. Cytochem. 27 (1979) 1148-1162. 
[30] M. Nakamura, Y. Abe, T. Tokunaga, Pathological significance of vascular endothelial growth factor A isoform expression in human câncer, Pathol. Int. 52 (2002) 331-339.

[31] S. A. Bustin, V. Benes, J. A. Garson, J. Hellemans, J. Huggett, M. Kubista, R. Mueller, T. Nolan, M. W. Pfaffl, G. L. Shipley, J. Vandesompele, C. T. Wittwer, The MIQE guidelines: minimum information for publication of quantitative Real-Time PCR Experiments, Clin. Chem. 55 (2009) 611-622.

[32] The Myc family of genes and proteins, involved in many aspects of cell metabolism, is subjected to a tight control in normal cells but becomes deregulated in most tumor cells. For a review, see: A. Albihn, J. I. Johnsen, M. A. Henriksson, MYC in oncogenesis and as a target for cancer therapies, Adv. Cancer Res. 107 (2010) 163-224.

[33] (a) J. Dwyer, H. Li, D. Xu, J.-P. Liu, Transcriptional regulation of telomerase activity - Roles of the the Ets transcription factor family, Ann. N. Y. Acad. Sci. 1114 (2007) 36-47.

(b) S. Kyo, M. Takakura, T. Fujiwara, M. Inoue, Understanding and exploiting hTERT promoter regulation for diagnosis and treatment of human cancers, Cancer Sci. 99 (2008) 1528-1538.

(c) M. Daniel, G. W. Peek, T. O. Tollefsbol, Regulation of the human catalytic subunit of telomerase (hTERT), Gene 498 (2012) 135-146.

[34] J. J. Heynekamp, W. M. Weber, L. A. Hunsaker, A. M. Gonzales, R. A. Orlando, L. M. Deck, D. L. V. Jagt, Substituted trans-stilbenes, including analogues of the natural product resveratrol, inhibit the human tumor necrosis factor alpha-induced activation of transcription factor nuclear factor KappaB, J. Med. Chem. 49 (2006) 7182-7189.

[35] L. A. Stivala, M. Savio, F. Carafoli, P. Perucca, L. Bianchi, G. Maga, L. Forti, U. M. Pagnoni, A. Albini, E. Prosperi, V. Vannini, Specific structural determinants are responsible for the antioxidant activity and the cell cycle effects of resveratrol, J. Biol. Chem. 276 (2001) 2258622594.

[36] S. Rodríguez-Nieto, M. A. Medina, A. R. Quesada, A re-evaluation of fumagillin selectivity towards endothelial cells, Anticancer Res. 21 (2001) 3457-3460. 